\title{
Alcanivorax balearicus sp. nov., isolated from Lake Martel
}

\author{
Raúl Rivas, ${ }^{1,2}$ Paula García-Fraile, ${ }^{1}$ Alvaro Peix, ${ }^{3}$ Pedro F. Mateos, ${ }^{1}$ \\ Eustoquio Martínez-Molina ${ }^{1}$ and Encarna Velázquez ${ }^{1}$ \\ ${ }^{1}$ Departamento de Microbiología y Genética, Universidad de Salamanca, Spain \\ ${ }^{2}$ Laboratorium voor Microbiologie, Vakgroep Biochemie, Fysiologie en Microbiologie, Universiteit \\ Gent KL, Ledeganckstraat 35, B-9000 Gent, Belgium \\ ${ }^{3}$ Instituto de Recursos Naturales y Agrobiología, IRNASA-CSIC, Salamanca, Spain
}

Correspondence

Raúl Rivas

raul@wwwedu-micro.usal.es
The genus Alcanivorax currently comprises four species, $A$. borkumensis, A. jadensis, A. venustensis and A. dieselolei, all of which were isolated from marine environments (Yakimov

\footnotetext{
Abbreviations: ITS, intergenic spacer; TP-RAPD, two-primers randomly amplified polymorphic DNA.

The GenBank/EMBL/DDBJ accession numbers for strain MACLO4 ${ }^{\top}$ are AY686709 (16S rRNA gene), EF091805 (small ITS), EF091804 (large ITS), AY683535 (partial alkB gene) and EF091802 (partial gyrB gene).

Figures showing the colony morphologies of strain $\mathrm{MACLO}^{\top}$ and Alcanivorax dieselolei $\mathrm{B}-5^{\top}$ grown on media containing Tween 20 , an electron micrograph of a cell of strain MACLO $4^{\top}$ grown on nutrient agar, and TP-RAPD profiles and phylogenetic trees based on 16S-23S ITS and partial alkB and $g y r B$ gene sequences and a table detailing the fatty acid profiles of strain MACLO $4^{\top}$ and recognized species of the genus Alcanivorax are available as supplementary material with the online version of this paper.
}

et al., 1998; Bruns \& Berthe-Corti, 1999; Fernández-Martínez et al., 2003; Liu \& Shao, 2005). Here we characterize a strain, designated MACL04 ${ }^{\mathrm{T}}$, which was isolated from water collected from Lake Martel, a subterranean saline lake in Mallorca (Balearic Islands), Spain. Strain MACL04 ${ }^{\mathrm{T}}$ is phylogenetically close to A. dieselole $\mathrm{B}-5^{\mathrm{T}}$ but, based on its phenotypic, chemotaxonomic and molecular characteristics, we propose that it should be considered to represent a novel species within the genus Alcanivorax.

Strain MACL04 ${ }^{\mathrm{T}}$ was isolated under aseptic conditions from water samples taken at a depth of $10 \mathrm{~cm}$, during a bacterial biodiversity study of Lake Martel. Under sterile conditions, a $200 \mathrm{ml}$ sample was filtered under vacuum through a membrane filter with a pore diameter of $45 \mu \mathrm{m}$ (Millipore). The membrane was placed on a plate containing YED medium $(0.5 \%$ yeast extract, $0.7 \%$ glucose and $2 \%$ agar, w/v $)$ supplemented with $1.5 \%(\mathrm{w} / \mathrm{v}) \mathrm{NaCl}$ and incubated at $28^{\circ} \mathrm{C}$. 
Cells of strain MACL04 ${ }^{\mathrm{T}}$ formed white-cream-coloured colonies on nutrient agar medium supplemented with $1.5 \%$ $\mathrm{NaCl}$. Optimum growth was observed on TPA medium $(1 \% \mathrm{v} / \mathrm{v}$ Tween $20,1 \% \mathrm{w} / \mathrm{v}$ peptone, $0.5 \% \mathrm{w} / \mathrm{v} \mathrm{NaCl}$, $0.01 \% \mathrm{w} / \mathrm{v} \mathrm{CaCl}_{2}$ and $1.5 \% \mathrm{w} / \mathrm{v}$ agar). On this medium, colonies of strain MACL $04^{\mathrm{T}}$ were opaque and showed bluegreen iridescence, whereas colonies of $A$. dieselole $\mathrm{B}-5^{\mathrm{T}}$ were transparent and glistening, without coloured iridescence (see Supplementary Fig. S1 available in IJSEM Online). Gram staining was carried out by using the procedure described by Doetsch (1981). Cells were gently suspended in sterile water, stained with $0.2 \%$ uranyl acetate and examined at $80 \mathrm{kV}$ with a Zeiss EM 209 transmission electron microscope (Peix et al., 2003). Cells of strain MACL04 ${ }^{\mathrm{T}}$ were Gram-negative, short rod-shaped $(1.1-1.3 \times 0.6-0.8 \mu \mathrm{m})$ and motile by means of a polar or subpolar flagellum (see Supplementary Fig. S2 available in IJSEM Online), whereas cells of A. dieselolei showed several lophotrichous flagella (see Table 1). The generation times of strain MACL04 ${ }^{\mathrm{T}}$ and A. dieselolei $\mathrm{B}-5^{\mathrm{T}}$ were compared using turbidimetry in liquid TPA medium (Koch, 1981). The results showed that A. dieselolei $\mathrm{B}-5^{\mathrm{T}}$ had a generation time of approximately $5 \mathrm{~h}$, whereas the generation time for strain MACL $04^{\mathrm{T}}$ was approximately $2.5 \mathrm{~h}$.

For sequencing of the 16S rRNA gene, DNA extraction was carried out as described previously (Rivas et al., 2001). Amplification of the gene and sequencing were performed according to methods described previously (Rivas et al., $2002 \mathrm{~b}$ ). An almost complete $16 \mathrm{~S}$ rRNA gene sequence was obtained and compared with sequences deposited in databases. The sequences were aligned using CLUSTAL_X software (Thompson et al., 1997) and distances were calculated according to the Kimura two-parameter method (Kimura, 1980). Phylogenetic trees were inferred using the neighbour-joining method (Saitou \& Nei, 1987) and bootstrap analysis was performed, based on 1000 resamplings. The MEGA2 package (Kumar et al., 2001) was used for all analyses. Comparison with sequences held in GenBank indicated that strain MACL04 ${ }^{\mathrm{T}}$ was very closely related to A. dieselolei (Figure 1). The 16S rRNA gene sequence of strain MACL $04^{\mathrm{T}}$ showed nearly $100 \%$ similarity to that of $A$. dieselolei $\mathrm{B}-5^{\mathrm{T}}$. Despite this fact, taking into account the morphological and growth behaviour differences between strain MACL04 $4^{\mathrm{T}}$ and $A$. dieselolei $\mathrm{B}-5^{\mathrm{T}}$, we performed a polyphasic study to establish the taxonomic status of strain MACL04 ${ }^{\mathrm{T}}$.

Two-primers randomly amplified polymorphic DNA (TPRAPD) patterns were analysed as described previously (Rivas et al., 2002a), using the primer pair 879F (5'GCCTGGGGAGTACGGCCGCA-3') and 1522R (5'AAGGAGGTGATCCANCCRCA-3'), which correspond to Escherichia coli positions 879-898 and 1509-1522, respectively. According to our previous results, strains showing the same pattern belong to the same species and different species display different TP-RAPD patterns (Rivas et al., 2001, 2004). Moreover, from results obtained previously, TPRAPD patterns are not strain dependent (Rivas et al., 2001) and in some cases the profiles can be slightly different in subspecies of the same species (Rivas et al., 2002a). Therefore, we analysed the TP-RAPD pattern of strain MACL $04^{\mathrm{T}}$ and compared it with those of the type strains of recognized species of the genus Alcanivorax (see

Table 1. Differential phenotypic characteristics among Alcanivorax balearicus sp. nov. strain MACLO4 ${ }^{\top}$ and recognized species of the genus Alcanivorax

Taxa: 1, strain MACL04 ${ }^{\mathrm{T}}$; 2, A. dieselolei; 3, A. borkumensis; 4, A. jadensis; 5, A. venustensis. Data from Yakimov et al. (1998), Bruns \& Berthe-Corti (1999), Fernández-Martínez et al. (2003), Liu \& Shao (2005) and this study. +, Positive, -, negative; W, weak; v, variable; ND, no data.

\begin{tabular}{|c|c|c|c|c|c|}
\hline Characteristic & 1 & 2 & 3 & 4 & 5 \\
\hline Motility/flagella arrangement & $\begin{array}{c}+/ \text { Polar or } \\
\text { subpolar flagellum }\end{array}$ & $\begin{array}{c}+/ \text { Lophotrichous } \\
\text { flagella }\end{array}$ & - & - & +/Polar flagella \\
\hline Ionic requirement & - & $\mathrm{Na}^{+}$ & Complex & $\mathrm{Na}^{+}$ & Complex \\
\hline Growth at $17 \% \mathrm{NaCl}$ & - & $\mathrm{W}^{*}$ & - & - & + \\
\hline Growth at $45^{\circ} \mathrm{C}$ & - & + & - & + & + \\
\hline Hydrolysis of Tween 20 after 4 days incubation & $-{ }^{*}$ & $+^{*}$ & ND & ND & ND \\
\hline \multicolumn{6}{|l|}{ Utilization of carbohydrates: } \\
\hline Glucose & $\mathrm{W}$ & - & - & - & - \\
\hline L-Arabinose & $\mathrm{W}$ & - & - & ND & - \\
\hline \multicolumn{6}{|l|}{ Utilization of organic acids: } \\
\hline Acetate & $\mathrm{W}$ & + & + & + & + \\
\hline Lactate & - & + & ND & ND & $\mathrm{V}$ \\
\hline Pyruvate & $+(\operatorname{acid} \mathrm{pH})$ & $+($ alkaline $\mathrm{pH})$ & + & + & + \\
\hline Propionate & $\mathrm{W}$ & $-{ }^{*}$ & + & ND & + \\
\hline
\end{tabular}

${ }^{\star}$ Data from this study. 


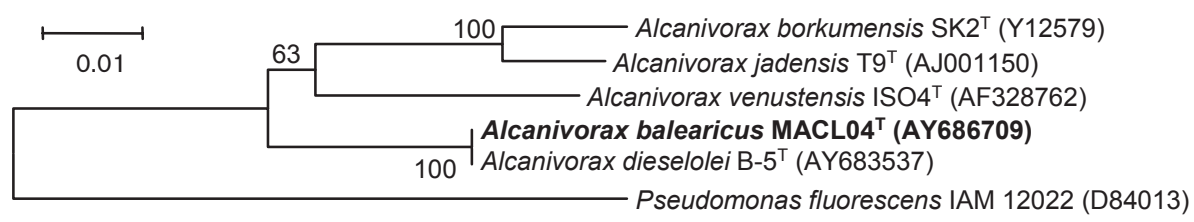

Fig. 1. Phylogenetic tree obtained using the neighbour-joining method based on nearly complete $16 \mathrm{~S}$ rRNA gene sequences of strain MACLO4 $4^{\top}$ and recognized species of the genus Alcanivorax. The significance of each branch is indicated by percentage bootstrap values calculated for 1000 subsets. Bar, 1 substitution per 100 nucleotides. The sequence of Pseudomonas fluorescens IAM 12022 was used as an outgroup.

Supplementary Fig. S3 available in IJSEM Online). The TPRAPD profiles of all these strains were different and the differences observed between $A$. dieselolei $\mathrm{B}-5^{\mathrm{T}}$ and strain MACL04 ${ }^{\mathrm{T}}$ indicated that they could belong to different species.

The 16S-23S intergenic spacer (ITS) region was amplified and sequenced as described by Liu \& Shao (2005). PCR amplification of the ITS region yielded two products, as occurs for all Alcanivorax species. Phylogenetic analysis based on the ITS sequences showed similar groupings to those obtained using the 16S rRNA gene and confirmed the close phylogenetic relationship between strain MACL04 ${ }^{\mathrm{T}}$ and $A$. dieselolei (see Supplementary Fig. S4 available in IJSEM Online). The sequences of the large and short ITS regions showed 97.2 and $98.8 \%$ similarities (ungapped) with respect to $A$. dieselolei $\mathrm{B}-5^{\mathrm{T}}$. As the genus Alcanivorax currently comprises only four species that are well separated phylogenetically, we could not come to any conclusions about the similarity among strains from different species. Nevertheless, the similarity values between strain MACL04 ${ }^{\mathrm{T}}$ and $A$. dieselole $\mathrm{B}-5^{\mathrm{T}}$ were similar to those found in different species of Pseudomonas that are phylogenetically closely related on the basis of $16 \mathrm{~S}$ rRNA gene sequences. For example, the ITS regions of Pseudomonas graminis and Pseudomonas lutea (GenBank accession nos DQ023307 and EF091800, respectively) exhibit nearly $99 \%$ similarity.

A fragment of the alkB gene was amplified and sequenced using the primers ALKBF (5'-TCAATACMGGDCAYGAG$3^{\prime}$ ) and ALKBR (5'-TAGTTSACSAYCTCCAGC-3'), which were designed in this study based on the conserved regions of the codifying genes for alkane hydrolase sequences from Alcanivorax species. The PCR conditions used were: preheating at $95^{\circ} \mathrm{C}$ for $9 \mathrm{~min} ; 35$ cycles of denaturation at $95^{\circ} \mathrm{C}$ for $1 \mathrm{~min}$, annealing at $50^{\circ} \mathrm{C}$ for $1 \mathrm{~min}$ and extension at $72{ }^{\circ} \mathrm{C}$ for $1 \mathrm{~min}$, and a final extension at $72{ }^{\circ} \mathrm{C}$ for $7 \mathrm{~min}$. Strain MACL $04^{\mathrm{T}}$ showed $94 \%$ similarity with respect to $A$. dieselolei $\mathrm{B}-5^{\mathrm{T}}$. Phylogenetic analysis based on the alkb gene yielded results similar to those obtained in the $16 \mathrm{~S}$ and ITS analyses, showing that strain MACL04 ${ }^{\mathrm{T}}$ and $A$. dieselolei $\mathrm{B}-$ $5^{\mathrm{T}}$ form a group together with $A$. venustensis that is phylogenetically separate from the other species of the genus Alcanivorax (see Supplementary Fig. S5 available in IJSEM Online).
Partial sequences of the $g y r B$ gene were obtained for strain MACL $04^{\mathrm{T}}$ and A. dieselole $i \mathrm{~B}-5^{\mathrm{T}}$, by using primers designed on the basis of conserved sequences of a hypervariable zone of this gene in Alcanivorax and other phylogenetically related species sequenced previously by Okamoto et al. (2004): GYRBUNIVF (5'-GGBCTBCAYGGBGTRGG-3') and GYRBUNIVR ( $5^{\prime}$-CCCGCWGARTCACCCTCC- $3^{\prime}$ ). The PCR conditions used were the same as those for the amplification of the alkb gene described above, except that the annealing temperature used was $52{ }^{\circ} \mathrm{C}$. Strain MACL $04^{\mathrm{T}}$ showed $94 \%$ similarity with respect to strain A. dieselolei B$5^{\mathrm{T}}$. Despite the fact that this value was higher than those obtained among other species of Alcanivorax, they are distant from a phylogenetic point of view and, as was observed in the case of the ITS region, similarity limits among the closely related species of this genus could not be established (see Supplementary Fig. S6 available in IJSEM Online). However, in the related genus Pseudomonas, similarity values greater than $95 \%$ for gyrB have been reported for several species, such as Pseudomonas kilonensis, Pseudomonas brassicacearum and Pseudomonas thivervalensis (Cladera et al., 2006).

Analysis of the fatty acid composition was performed as described by Zimmermann et al. (1998) using the culture conditions recommended by Yakimov et al. (1998). This analysis was performed at the DSMZ (Deutsche Sammlung von Mikroorganismen und Zellkulturen, Braunschweig, Germany) as was also the case for A. dieselolei. The cellular fatty acid pattern of strain MACL $04^{\mathrm{T}}$ comprised 17 different fatty acids (see Supplementary Table S1 available in IJSEM Online). The major fatty acid of strain MACL $04^{\mathrm{T}}$ was $\mathrm{C}_{19: 0}$ cyclo $\omega 8 c(29.33 \%)$. The fatty acids $\mathrm{C}_{16: 0}(24.40 \%)$ and $\mathrm{C}_{18: 1} \omega 7 c(14.68 \%)$ were also present in high amounts. Other fatty acids were present in smaller amounts, including $\mathrm{C}_{16: 1} \omega 7 c(7.90 \%), \mathrm{C}_{12: 0} 3-\mathrm{OH}(5.84 \%), \mathrm{C}_{12: 0}(5.46 \%)$, $\mathrm{C}_{10: 0}(2.56 \%), \mathrm{C}_{16: 1} \omega 8 c(2.10 \%), \mathrm{C}_{17: 0}$ (1.49\%), $\mathrm{C}_{17: 0}$ cyclo $(1.45 \%)$ and $\mathrm{C}_{12: 0} 2-\mathrm{OH}(1.38 \%)$. Fatty acids $\mathrm{C}_{11: 0}$, $\mathrm{C}_{18: 0}, 11$-methyl $\mathrm{C}_{18: 1} \omega 7 c, \mathrm{C}_{20: 2} \omega 6,9 c$, an unidentified fatty acid with an equivalent chain-length value of 12.484 and an unidentified fatty acid with an equivalent chain-length value of 11.799 were present in amounts of less than $1 \%$. This profile has several differences with respect to that of $A$. dieselolei (Liu \& Shao, 2005). The major fatty acid of strain MACL $04^{\mathrm{T}}, \mathrm{C}_{19: 0}$ cyclo $\omega 8 c$, was not the main fatty acid in $A$. 
dieselolei. Such a large amount of $\mathrm{C}_{19: 0}$ cyclo $\omega 8 \mathrm{c}$ has not been reported previously for Alcanivorax species. The fatty acid $\mathrm{C}_{18: 1} \omega 7 \mathrm{c}$ was one of the two major fatty acids in $A$. dieselolei, but not in strain MACL $04^{\mathrm{T}}$. The fatty acid $\mathrm{C}_{16: 1} \omega 8 c$ present in strain MACL04 ${ }^{\mathrm{T}}$ was not detected in $A$. dieselolei or in the other Alcanivorax species. Quantitative differences were detected for $\mathrm{C}_{16: 0}, \mathrm{C}_{16: 1} \omega 7 c$ and $\mathrm{C}_{12: 0} 3$ $\mathrm{OH}$ between strain MACL $04^{\mathrm{T}}$ and A. dieselolei $\mathrm{B}-5^{\mathrm{T}}$.

DNA for base composition analysis was prepared according to Chun \& Goodfellow (1995). The G + C content of the DNA was determined using the thermal denaturation method (Mandel \& Marmur, 1968). The DNA G+C content of strain MACL04 ${ }^{\mathrm{T}}$ was $62.8 \mathrm{~mol} \%$. DNA-DNA hybridization was carried out using the method of Ezaki et al. (1989), following the recommendations of Willems et al. (2001). The results obtained showed $67 \%( \pm 1 \%$, SD of three determinations) DNA-DNA relatedness between strain MACL04 ${ }^{\mathrm{T}}$ and A. dieselolei $\mathrm{B}-5^{\mathrm{T}}$.

The phenotypic characterization was performed as described by Yakimov et al. (1998), Bruns \& Berthe-Corti (1999) and Liu \& Shao (2005). In all the tests, A. dieselolei B$5^{\mathrm{T}}$ was used as a reference. Utilization of carbon sources was tested using SM1 medium (Yakimov et al., 1998), supplemented with $1.5 \%(\mathrm{w} / \mathrm{v}) \mathrm{NaCl}$ and $1 \%(\mathrm{w} / \mathrm{v})$ of the various carbon sources (Table 1). The $\mathrm{pH}$ indicator Bromothymol blue $(0.05 \%, \mathrm{w} / \mathrm{v})$ was included in the media. Assimilation of n-alkanes (decane, tetradecane, hexadecane and eicosane) was tested as described by Bruns \& BertheCorti (1999). The physiological and biochemical characterizations were completed using API 20NE strips (bioMérieux), according to the manufacturer's instructions. The medium supplied with the API 20NE test strips was supplemented with $1.5 \%(\mathrm{w} / \mathrm{v}) \mathrm{NaCl}$ before use. The temperature range for growth was determined by incubating cultures in YED medium supplemented with $1.5 \%(\mathrm{w} / \mathrm{v})$ $\mathrm{NaCl}$ at $4-45^{\circ} \mathrm{C}$. The $\mathrm{pH}$ range was determined using YED medium, with final $\mathrm{pH}$ values of 4.0-10.0. Salt tolerance was studied using nutrient agar medium (Difco, BectonDickinson) containing $0-20 \%(\mathrm{w} / \mathrm{v}) \mathrm{NaCl}$. Antibiotic susceptibility tests were performed as described by Liu \& Shao (2005).

The phenotypic characteristics of strain MACL $04^{\mathrm{T}}$ are given in Table 1. Unlike other species of the genus Alcanivorax, strain MACL04 ${ }^{\mathrm{T}}$ did not require $\mathrm{NaCl}$ for growth. Strain MACL $04^{\mathrm{T}}$ was unable to grow at $45^{\circ} \mathrm{C}$, whereas $A$. dieselolei can grow at this temperature. Utilization of glucose and Larabinose by strain MACL $04^{\mathrm{T}}$ was weakly positive, whereas A. dieselolei was unable to use carbohydrates as was reported previously by Liu \& Shao (2005). Hydrolysis of Tween 20 was negative after 4 days incubation for strain MACL0 $4^{\mathrm{T}}$, whereas at this time $A$. dieselole $\mathrm{B}-5^{\mathrm{T}}$ produced abundant lipases (tweenases). Strain MACL04 ${ }^{\mathrm{T}}$ differed in the use of acetate, lactate and propionate as sole carbon sources. Use of pyruvate was positive in both strain MACL04 ${ }^{\mathrm{T}}$ and $A$. dieselolei $\mathrm{B}-5^{\mathrm{T}}$; however, acid $\mathrm{pH}$ was produced by strain
MACL04 ${ }^{\mathrm{T}}$, whereas alkaline $\mathrm{pH}$ was produced by $A$. dieselolei $\mathrm{B}-5^{\mathrm{T}}$.

The phenotypic differences together with differences observed in the chemotaxonomic and molecular analyses support the classification of strain MACL $04^{\mathrm{T}}$ as representing a novel species of the genus Alcanivorax, for which the name Alcanivorax balearicus sp. nov. is proposed.

\section{Description of Alcanivorax balearicus sp. nov.}

Alcanivorax balearicus (ba.le.a' ri.cus. L. masc. adj. balearicus of the Balearic Islands, where the organism was isolated).

Gram-negative, aerobic, rod-shaped cells. Motile by means of a polar or subpolar flagellum. Colonies on nutrient agar supplemented with $1.5 \%(\mathrm{w} / \mathrm{v}) \mathrm{NaCl}$ are circular, smooth and white-cream-coloured; colonies are opaque and mucoid with blue-green iridescence on media containing Tween 20 , and usually $2-4 \mathrm{~mm}$ in diameter within 5 days at $28^{\circ} \mathrm{C}$. Oxidase- and catalase-positive. Urease-negative. Phylogenetically related to members of the family Alcanivoracaceae. Halotolerant; ionic supplements are not required for growth. Major fatty acids are $\mathrm{C}_{19: 0}$ cyclo $\omega 8 c$, $\mathrm{C}_{16: 0}$ and $\mathrm{C}_{18: 1} \omega 7 c$, fatty acids $\mathrm{C}_{16: 1} \omega 7 c, \mathrm{C}_{12: 0} 3-\mathrm{OH}, \mathrm{C}_{12: 0}$, $\mathrm{C}_{10: 0}, \mathrm{C}_{16: 1} \omega 8 c, \mathrm{C}_{17: 0}, \mathrm{C}_{17: 0}$ cyclo, $\mathrm{C}_{12: 0} 2-\mathrm{OH}, \mathrm{C}_{18: 0}, 11-$ methyl $\mathrm{C}_{18: 1} \omega 7 c, \mathrm{C}_{20: 2} \omega 6,9 c$ and $\mathrm{C}_{11: 0}$ are present in smaller amounts. Growth occurs in $\mathrm{NaCl}$ at concentrations up to $15 \%(\mathrm{w} / \mathrm{v})$, although $\mathrm{NaCl}$ is not required for growth. Temperature range for growth is $4-37^{\circ} \mathrm{C}$ (optimal growth occurs at $28^{\circ} \mathrm{C}$ ). $\mathrm{pH}$ range for growth is $5.5-9$ (optimal growth occurs at $\mathrm{pH} 7$ ). Negative for production of lipase in media containing Tween 20 after 4 days incubation at $28^{\circ} \mathrm{C}$; weak and slow production is detected after incubation for 1 week. Aesculin, casein, gelatin and starch are not hydrolysed and arginine dihydrolase and $\beta$-galactosidase activities and indole production and nitrate reduction are negative. Can grow using glucose and other carbohydrates as a carbon source. Decane, tetradecane, hexadecane, eicosane, adipate, caproate, citrate, malate, mannitol, phenylacetate, glutarate, quinate and pyruvate can be used as sole carbon sources. Weak growth occurs with acetate, propionate, glucuronate and L-arabinose. Does not grow with lactate, $N$ acetylglucosamine, gentiobiose, maltose, D-mannose, xylose or sucrose. Sensitive to neomycin and polymyxin B and resistant to cefuroxime, ampicillin, penicillin, erythromycin and ciprofloxacin. The DNA G $+\mathrm{C}$ content of the type strain is $62.8 \mathrm{~mol} \%$.

The type strain, MACL04 ${ }^{\mathrm{T}}\left(=\mathrm{LMG} 22508^{\mathrm{T}}=\mathrm{CECT}^{2} 683^{\mathrm{T}}\right)$, was isolated from water from Lake Martel, a subterranean saline lake in the Balearic Islands, Spain.

\section{Acknowledgements}

This work was supported by the CAICYT-DGES and the JCyL (Spanish Government). We are grateful to the DSMZ staff for chemotaxonomic analyses. R. R. acknowledges a $\mathrm{PhD}$ fellowship from Ministerio de Educación y Ciencia. 


\section{References}

Bruns, A. \& Berthe-Corti, L. (1999). Fundibacter jadensis gen. nov., sp. nov., a new slightly halophilic bacterium, isolated from intertidal sediment. Int J Syst Bacteriol 49, 441-448.

Chun, J. \& Goodfellow, M. (1995). A phylogenetic analysis of the genus Nocardia with $16 \mathrm{~S}$ rRNA gene sequences. Int J Syst Bacteriol 45, 240-245.

Cladera, A. M., Sepúlveda-Torres, L. del C., Valens-Vadell, M., Meyer, J.-M., Lalucat, J. \& Garcia-Valdés, E. (2006). A detailed phenotypic and genotypic description of Pseudomonas strain OX1. Syst Appl Microbiol 29, 422-430.

Doetsch, R. N. (1981). Determinative methods of light microscopy. In Manual of Methods for General Bacteriology, pp. 21-33. Edited by P. Gerdhardt, R. G. E. Murray, R. N. Costilow, E. W. Nester, W. A. Wood, N. R. Krieg \& G. B. Phillips. Washington: American Society for Microbiology.

Ezaki, T., Hashimoto, Y. \& Yabuuchi, E. (1989). Fluorometric deoxyribonucleic acid-deoxyribonucleic acid hybridization in microdilution wells as an alternative to membrane filter hybridization in which radioisotopes are used to determine genetic relatedness among bacterial strains. Int J Syst Bacteriol 39, 224-229.

Fernández-Martínez, J., Pujalte, M. J., García-Martínez, J., Mata, M., Garay, E. \& Rodríguez-Valera, F. (2003). Description of Alcanivorax venustensis sp. nov. and reclassification of Fundibacter jadensis DSM $12178^{\mathrm{T}}$ (Bruns and Berthe-Corti 1999) as Alcanivorax jadensis comb. nov., members of the emended genus Alcanivorax. Int J Syst Evol Microbiol 53, 331-338.

Kimura, M. (1980). A simple method for estimating evolutionary rates of base substitutions through comparative studies of nucleotide sequences. J Mol Evol 16, 111-120.

Koch, A. L. (1981). Growth measurement. In Manual of Methods for General Bacteriology, pp. 21-33. Edited by P. Gerdhardt, R. G. E. Murray, R. N. Costilow, E. W. Nester, W. A. Wood, N. R. Krieg \& G. B. Phillips. Washington: American Society for Microbiology.

Kumar, S., Tamura, K., Jakobsen, I. B. \& Nei, M. (2001). MEGA2: Molecular Evolutionary Genetics Analysis software. Bioinformatics 17, 1244-1245.

Liu, C. \& Shao, Z. (2005). Alcanivorax dieselolei sp. nov., a novel alkane-degrading bacterium isolated from sea water and deep-sea sediment. Int J Syst Evol Microbiol 55, 1181-1186.

Mandel, M. \& Marmur, J. (1968). Use of ultraviolet absorbance temperature profile for determining the guanine plus cytosine content of DNA. Methods Enzymol 12B, 195-206.
Okamoto, T., Maruyama, A., Imura, S., Takeyama, H. \& Naganuma, T. (2004). Comparative phylogenetic analyses of Halomonas variabilis and related organisms based on $16 \mathrm{~S}$ rRNA, gyrB and ectBC gene sequences. Syst Appl Microbiol 27, 323-333.

Peix, A., Rivas, R., Mateos, P. F., Martínez-Molina, E., RodríguezBarrueco, C. \& Velázquez, E. (2003). Pseudomonas rhizosphaerae sp. nov., a novel species that actively solubilizes phosphate in vitro. Int J Syst Evol Microbiol 53, 2067-2072.

Rivas, R., Velázquez, E., Valverde, A., Mateos, P. F. \& MartínezMolina, E. (2001). A two primers random amplified polymorphic DNA procedure to obtain polymerase chain reaction fingerprints of bacterial species. Electrophoresis 22, 1086-1089.

Rivas, R., Velázquez, E., Palomo, J. L., Mateos, P., GarcíaBenavides, P. \& Martínez-Molina, E. (2002a). Rapid identification of Clavibacter michiganensis subspecies sepedonicus using two primers random amplified polymorphic DNA (TP-RAPD) fingerprints. Eur J Plant Pathol 108, 179-184.

Rivas, R., Velázquez, E., Willems, A., Vizcaíno, N., Subba-Rao, N. S., Mateos, P. F., Gillis, M., Dazzo, F. B. \& Martínez-Molina, E. (2002b). A new species of Devosia that forms a unique nitrogen-fixing rootnodule symbiosis with the aquatic legume Neptunia natans (L.f.) Druce. Appl Environ Microbiol 68, 5217-5222.

Rivas, R., Abril, A., Trujillo, M. E. \& Velázquez, E. (2004). Sphingomonas phyllosphaerae sp. nov., from the phyllosphere of Acacia caven in Argentina. Int J Syst Evol Microbiol 54, 2147-2150.

Saitou, N. \& Nei, M. (1987). The neighbor-joining method: a new method for reconstructing phylogenetic trees. Mol Biol Evol 4, 406-425.

Thompson, J. D., Gibson, T. J., Plewniak, F., Jeanmougin, F. \& Higgins, D. G. (1997). The CLUSTAL_X windows interface: flexible strategies for multiple sequence alignment aided by quality analysis tools. Nucleic Acid Res 25, 4876-4882.

Willems, A., Doignon-Bourcier, F., Goris, J., Coopman, R., de Lajudie, P., De Vos, P. \& Gillis, M. (2001). DNA-DNA hybridization study of Bradyrhizobium strains. Int J Syst Evol Microbiol 51, 1315-1322.

Yakimov, M. M., Golyshin, P. N., Lang, S., Moore, E. R. B., Abraham, W.-R., Lünsdorf, H. \& Timmis, K. N. (1998). Alcanivorax borkumensis gen. nov., sp. nov., a new, hydrocarbon-degrading and surfactantproducing marine bacterium. Int J Syst Bacteriol 48, 339-348.

Zimmermann, O., Spröer, C., Kroppenstedt, R. M., Fuchs, E., Köchel, H. G. \& Funke, G. (1998). Corynebacterium thomssenii sp. nov., a Corynebacterium with $N$-acetyl- $\beta$-glucosaminidase activity from human clinical specimens. Int J Syst Bacteriol 48, 489-494. 